\title{
STUDIUM SPODNOBADENSKÝCH BAZÁLNÍCH KLASTIK V OBLASTI PODZEMNÍHO ZÁSOBNÍKU PLYNU LOBODICE
}

\author{
The study of the Lower Badenian (Miocene) basal clastic sediments in Lobodice \\ underground gas storage area
}

\author{
David Blaško', Slavomír Nehyba', Anita Bartakovics² \\ 'Ústav geologických věd PřF MU, Kotláŕská 2, 61137 Brno; e-mail: 309581@mail.muni.cz \\ ${ }^{2}$ RWE Gas Storage s. r. o., Geo-services, Pražská 158, 64200 Brno
}

(24-24 Prostějov)

Key words: Carpathian Foredeep, Miocene, Lower Badenian sediments, facies analysis, clast petrography and provenance

\begin{abstract}
The depositional environment and the provenance of the Lower Badenian basal clastics in the area of Lobodice subsurface gas storage were described during the studies of these sediments.

Drill cores of Lobodice wells were studied in the total length of $110 \mathrm{~m}$ for the purpose of depositional environment evaluation. The textures and structures were described on these cores and on this basis three lithofacies were recognized. The lithofacies A is represented by grey matrix supported, granule conglomerate, very poorly sorted. This lithofaces has been interpreted as the product of deposition of a coarse grained delta. The lithofacies $B$ is formed by fine and medium sandstone with ripple cross lamination, very well sorted sandstone. This facies was interpreted as the result of a relatively low energy of traction current, probably deposited in marine environment. The lithofacies $C$ is formed by greyish clay siltstone, locally with planar lamination and common bioturbation. The lithofacies $C$ was interpreted as the product of deposition in the offshore condition (outer part of the shelf?).

The results of pebble analysis and analysis of the chemistry of garnets and rutiles were used for the evaluation of the source areas of the Lower Badenian basal clastics.

Pebble analysis shows that the studied Lower Badenian clastics are polymict. Grey limestones dominate in the pebble spectra and also often represent the largest clasts. Light-coloured limestones, shales and graywackes (most probably Culmian), quartzes and dolomites are relatively common. The content of pebbles of crystalline rocks is relative low. These results indicate the prevalence of sedimentary rocks in the source area and/or recycling of the source material. This results together with garnet and rutile analysis point to the source from the Culmian rock of Drahanská Vrchovina Upland and Nízký Jeseník Highland (especially the rocks of the Myslejovice Formation) and also probably from the Carpathian Flysch Belt.
\end{abstract}

Úvod

Vrtný průzkum v oblasti obce Lobodice v Hornomoravském úvalu začal již v roce 1958. Během následujících téměř 50 let bylo na tomto území odvrtáno celkem 62 sond, které poskytly četné údaje především o sedimentech střední části karpatské př̀edhlubně. Část jader byla archivována, ale v důsledku záplav v oblasti Podzemního zásobníku plynu Lobodice se do dnešní doby dochovalo pouze $110 \mathrm{~m}$ jader, ovšem se značným postižením stavebních znaků sedimentu. Některé výsledky zpracování těchto jader jsou náplní předloženého př́spěvku. Výsledky studia bazálních klastik byly dále využity při reinterpretaci 3D reflexní seismiky naměřené $\mathrm{v}$ roce 2010 a také při tvorbě geologického modelu.

\section{Geologická situace}

Karpatská předhlubeň na Moravě je součástí periferních alpsko-karpatských pánví v předpolí flyšových jednotek. Dnes zabírá větší části moravských úvalů, Vyškovské a Moravské brány, Ostravsko, Opavsko a pokračuje na J do molasové zóny Rakouska a na $\mathrm{S}$ do karpatské předhlubně Polska. Neogenní sedimenty předhlubně na Moravě jsou v převážné míře v autochtonní pozici, bud' před čelem př́krovů, na nich nebo pod nimi. Částečně jsou také $\mathrm{v}$ paraautochtonní pozici nebo byly zavrásněny do čel prííkrovů (Brzobohatý - Cicha 1993). V raných fázích vývoje karpatské předhlubně (eggenburg, ottnang) zřejmě vystupovala zájmová oblast dnešního Hornomoravského úvalu jako nezaplavená elevace. Nejstarší výplň karpatské předhlubně v blízkém okolí zájmové oblasti je stratigraficky řazena ke karpatu. Karpatské sedimenty jsou známé v. od Lobodic, např. z vrtu Vlkoš 1 (Brzobohatý et al. 2003). Sedimentační prostor Hornomoravského úvalu v období spodního badenu vytvářel záliv, který bezprostředně souvisel se samotnou pánví (Zapletal 2004, 2005). Pliocenní a kvartérní denudace však tyto sedimenty postihla značnou měrou, takže dnes pozorujeme pouze relikty výplně karpatské předhlubně (Brzobohatý - Cicha 1993).

Spodnobadenská bazalní klastika v oblasti Lobodic jsou spojována s tzv. lobodickou strukturou, což je elevace předneogenního podloží, která byla při spodnobadenské transgresi zaplavena. Ve vrstevním sledu jsou spodnobadenská bazální klastika následována sedimentací badenských vápnitých jílů - „téglư“, což dokumentuje nárůst hloubky depozičního prostředí (Buday - Paulík 1959; Onderka 1992; Svatuška et al. 1989). Schematická mapa studované oblasti je na obrázku 1.

\section{Metodika}

Předmětem studia byla vrtná jádra $\mathrm{z}$ lobodických vrtů. Popsána byla vrtná jádra v celkové délce $110 \mathrm{~m}$. Sedimenty byly klasifikovány podle Kukala (1985) a byly u nich 


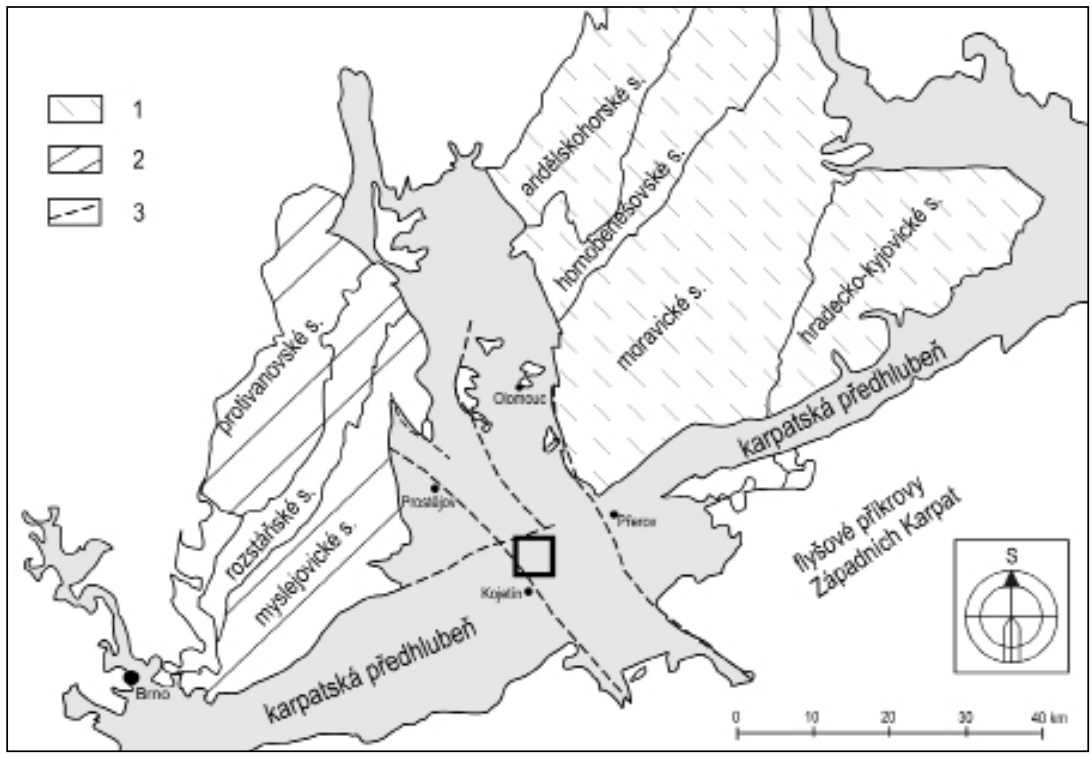

Obr. 1: Schematická mapa širšího okolí studované oblasti (modifikováno podle Chába et al. 2007). Studovaná oblast je označena čtvercem. 1 - jesenický kulm, 2 - drahanský kulm, 3 - zlomy. Šedou barvou je vybarvena oblast karpatské předhlubně.

Fig. 1: Schematic map of the broader surroundings of the studied area (according to Cháb et al. 2007). The study area is marked by square. 1 - the Jeseniky Culm, 2 - the Drahany Culm, 3 - faults. The grey color marks the area of the Carpathian Foredeep.

metrů. Střední velikost zrna se pohybuje v rozmezí od 1,7 do $3,6 \mathrm{~mm}$. Vytřídění je špatné až velmi špatné $(\sigma=1,7-2,6)$. Množství písčité frakce se pohybuje mezi 12 a $34 \%$. Prachovitá frakce je mezi 1 a $22 \%$. U dvou vrtů byl rozpoznán trend zjemnění do nadloží ( $v$ řádu několika $m$ ).

Zastoupení litofacie B je 0,3\%. Jedná se o světle šedý, slídnatý, čeřinovitě laminovaný, jemnozrnný až střednozrnný pískovec. Stř̌ední velikost zrna dosahuje hodnoty $0,195 \mathrm{~mm}$. Vytř́idění je velmi dobré $(\sigma=0,15)$. Pyritické konkrece jsou časté. Litofacie tvoří pouze $30 \mathrm{~cm}$ mocnou vrstvu.

Litofacie C tvoří 16,6\%. Je tvořena světle šedým až bělavě šedým jílovitým prachovcem. Prachovec je místy masivní, jindy horizontálně laminovaný nebo se rytmicky střídají relativně hrubozrnnější tmavé vrstvičky a vrstvičky světlejší a jemnozrnnější o mocnostech max.

popsány texturní a strukturní znaky. Na tomto základě byly následně vyčleněny litofacie. Následná interpretace litofacií byla zpracována podle Kukala (1986), Mialla (1996) a Nicholse (1999).

K petrografické analýze bylo vybráno osm vzorků vrtných jader badenských bazálních klastik z pěti vrtů (Lo-7, Lo-41, Lo-45, Lo-54, Lo-56). U každého vzorku bylo v průměru určeno 97 klastů o velikosti nad $4 \mathrm{~mm}$ (osa a). Zaoblení bylo hodnoceno dle Powerse (1953). Vzhledem $\mathrm{k}$ průmyslovému využití předmětných sedimentů soukromou společností jsou konkrétní údaje o vrtech a hloubkách důvěrnou informací.

$\mathrm{Na}$ čtyřech vybraných vzorcích bazálních klastik byl analyzován chemismus granátu (celkem 36 analyzovaných zrn) a rutilu (celkem 13 analyzovaných zrn). Počet zrn je roven počtu analýz. Analýzy byly provedeny pomocí elektronové mikrosondy CAMECA SX 100 na pracovišti elektronové mikroskopie a mikroanalýzy ÚGV PřF MU.

\section{Výsledky faciální analýzy a interpretace}

$\mathrm{V}$ rámci studovaných jader byly vyčleněny 3 litofacie. Litofacie A je na bázi sedimentárního sledu a má největší zastoupení. Z celkové délky popsaných jader tvořila $83 \%$. Jedná se o světle šedý až bělavě šedý, špatně vytříděný drobnozrnný slepenec až štěrčík, nestejnoměrně zrnitý a proměnlivě zpevněný s maximální velikostí valounů 2 až $7 \mathrm{~cm}$ (množství je př̀ibližně do $5 \%$ ). Výjimečně jsou př́tomny valouny o velikosti až $10 \mathrm{~cm}$. Ve štěrcích jsou často př́tomny intraklasty vápnitých jílovitých prachovců, velké až $3 \mathrm{~cm}$ (maximální osa a). Valouny jsou zejména subangulární a suboválné. Ve zpevněných polohách je rozeznatelná podpůrná struktura písčité základní hmoty, výjimečně se objevuje i podpůrná struktura klastů. Facie vytvárí polohy mocné od několika metrů až po desítky několika $\mathrm{cm}$. Místy byl zjištěn vyšší podíl písčité frakce. Litofacie $\mathrm{C}$ vytvárí polohy od několika centimetrů až po několik metrů. Velmi častá je bioturbace. Objevují se i schránky měkkýšů a rybí zbytky. Střední velikost zrna je $\mathrm{v}$ rozmezí 0,009 až $0,028 \mathrm{~mm}$. Vytrî́dění je velmi dobré ( $\sigma$ $=0,008-0,02)$.

Relativně špatné vytř́ídění, častá podpůrná struktura písčité matrix, masivní charakter, četné intraklasty jílovitého prachovce, by mohly spojovat litofacii A se sedimentací z nekohezivních úlomkotoků. Přítomnost zaoblených valounů relativně široké provenience by mohla ukazovat na jejich předchozí fluviální transport. Vzhledem k poznatkům o spodnobadenské sedimentaci z přilehlých oblastí karpatské předhlubně jsou sedimenty litofacie A interpretovány jako produkty depozice hrubozrnné delty. Litofacie B ukazuje na trakční sedimentaci ve spodním proudovém režimu $\mathrm{v}$ mělkovodním/mělkomořském prostředí. Přesto, že kvalita vrtného jádra nedovolila jednoznačnou identifikaci typu čeřin, jsou tyto struktury spojovány s činností vlnění (dobré vytřídění, pozice v rámci depoziční sukcese). Litofacie $\mathrm{C}$ je spojována se sedimentací $\mathrm{v}$ rámci mělkého moře. Výrazné zastoupení jílovité a prachovité frakce, rytmicita, horizontální laminace, četné bioturbace a občasné vložky jemnozrnného písku ukazují na rozdíly $\mathrm{v}$ rychlosti přínosu materiálu a podmínek sedimentace. Vyšší mocnost sedimentů litofacie $\mathrm{C}$ je pak spojována spíše s distálnějšími partiemi mělkého moře („vnější šelf“). Střídání těles facie A a facie C může být spojováno s bazálními partiemi hrubozrnné delty („bottomset“ či „toeset“).

\section{Výsledky petrografie a interpretace}

Výsledky petrografické analýzy jsou prezentovány na obrázku 2 . Z výsledků petrografické analýzy vyplývá, 


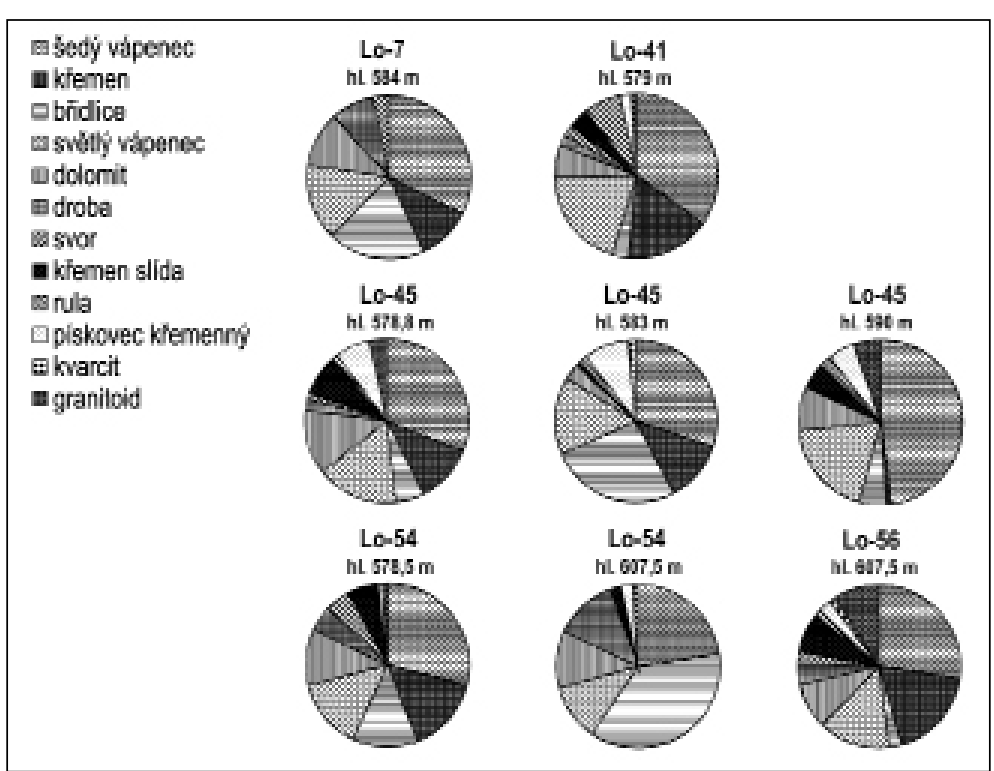

Obr. 2: Výsledky valounové analýzy. U metráže vzorků byla z důvodu utajení dat přičtena hodnota $\mathrm{x}$.

Fig. 2: The results of clast petrography analysis. The depth of samples was changed by the same value for data secrecy purposes.

že se jedná o slepence polymiktní. Největší zastoupení mají ve vzorcích šedé (zřejmě devonské) vápence (od 21 do $48 \%$ ). Klasty vápenců jsou především oválné až suboválné. Poměrně vysoké zastoupení ve všech vzorcích má také světlý (zřejmě jurský) vápenec (od 10 do $20 \%$ ), jehož valouny jsou také oválné až suboválné. Sedimentární břidlice (od 3 do $35 \%$ ) a droby (od 0 do $12 \%$ ) byly více zastoupeny ve vzorcích v s. části lobodické oblasti. Jejich valouny byly suboválné až oválné. Dále byly ve vzorcích zastoupeny především subangulární valouny křemene (od 0 do $18 \%$ ).

Z dobrého zaoblení valounů šedého vápence by bylo možné předpokládat jejich delší transport, ovšem rychlost zaoblení vápenců je relativně značná (Kukal 1983), což znamená, že vápence nemusely prodělat transport výrazně dlouhý. Současný povrchový výskyt vápenců devonského stáří v blízkosti zájmové oblasti je ve formě individuálních výchozů přibližně na území mezi městy Prostějov, Olomouc a Přerov - přibližně $15 \mathrm{~km}$ sz. až sv. od studované oblasti (Dlabač - Menčík 1964).

Podobná situace se zaoblením je také u světlých vápenců. Jejich zdrojovou oblastí by mohly být jurské vápence, jejichž současný povrchový výskyt je přibližně $25 \mathrm{~km}$ jv. od zájmové oblasti.

Suboválnost až oválnost valounů kulmských sedimentárních břidlic a drob naznačují delší transport, ovšem tyto horniny se zaoblují také relativně rychle (Kukal 1983). Ze zaoblení, výskytu především v s. části zájmové oblasti, ze zjištěné převahy břidlic nad drobami ve valounovém materiálu a $\mathrm{z}$ polohy současného povrchového výskytu kulmských hornin lze předpokládat, že materiál byl primárně přinášen z oblasti myslejovického souvrství Drahanské vrchoviny (především spodní části souvrství) a moravického souvrství kulmu Nízkého Jeseníku. Nejbližší výskyt hornin myslejovického souvrství je v současnosti vzdálen přibližně $13 \mathrm{~km}$ z. směrem a horniny moravického souvrství přibližně $13 \mathrm{~km}$ sv. směrem.

Křemenné valouny jsou výrazně odolnější vưči opracování než valouny vápenců. Ve studovaném případě jsou převážně subangulární. Možným primárním zdrojem jsou horniny krystalinika (např. horniny masivu hornomoravského úvalu, dle Dudka 1980). V př́padě valounů křemene je však obvykle nutno uvažovat možnost redepozice ze starších sedimentů, např̀. $\mathrm{z}$ račických a lulečských slepenců myslejovického souvrství, prrípadně slepenců hornobenešovského souvrství. Na prrípadnou redepozici by mohla ukazovat přítomnost valounů granitoidů. Ty jsou nalézány především v j. části lobodické oblasti, kde tvoři do $9 \%$ valounové frakce. Porovnání složení vzorků ve vertikálním sledu bylo možné u dvou sond. Z porovnání vyplývá, že do nadloží přibývá křemenných valounů. Nárůst role křemene směrem vzhůru v sedimentárním sledu může odrážet vyšší roli redepozice a recyklace ve zdrojové oblasti.

\section{Analýza granátů a interpretace}

Podle dosažených výsledků chemismu granátů byly vyčleněny 3 skupiny. Na obrázku 3 jsou znázorněny výsledky chemismu detritických granátů ze 4 analyzovaných vzorků odebraných z litofacie A. První a dominantní skupinou granátů jsou grosulár-almandiny s variabilní pyropovou a spessartinovou komponentou: $\mathrm{PRP}_{(4-16)}$, $\operatorname{SPS}_{(0-19)}, \operatorname{ALM}_{(56-77)}, \mathrm{GRS}_{(11-28)}, \mathrm{AND}_{(1-4)}$. Tato skupina tvoř́

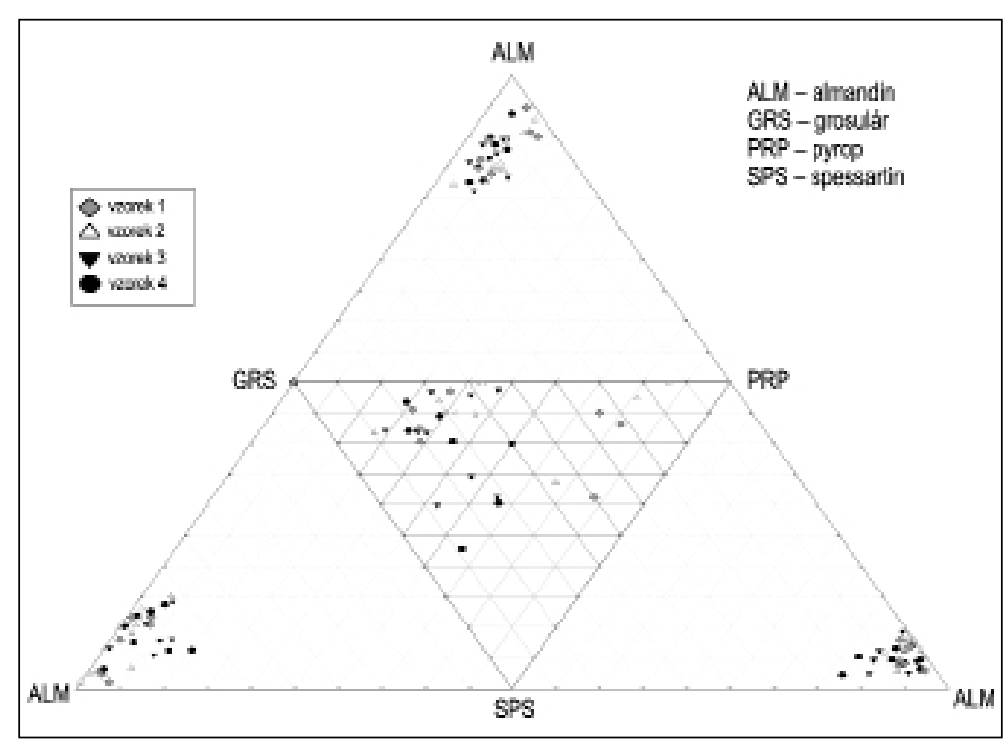

Obr. 3: Výsledky analýzy granátů zobrazené v ternárním diagramu. Fig. 3: The results of garnet analysis displayed in a ternary diagram. 
$72 \%$ z celkového počtu analyzovaných zrn. Grosulár-almandiny s variabilní pyropovou a spessartinovou komponentou jsou obsaženy ve všech čtyřech vzorcích. Druhá skupina je tvořena almandiny se zvýšenou pyropovou komponentou: $\mathrm{PRP}_{(6-16)}, \mathrm{SPS}_{(3-11)}, \mathrm{ALM}_{(68-83)}, \mathrm{GRS}_{(2-10)}, \mathrm{AND}_{(1-3)}$. Tato skupina tvoří $22 \% \mathrm{z}$ celkového počtu analyzovaných zrn. Tato skupina byla identifikována ve všech studovaných vzorcích. Třetí skupinu tvoří grosuláry: $\mathrm{PRP}_{(0)}, \mathrm{SPS}_{(0)}, \mathrm{ALM}_{(0)}$, $\mathrm{GRS}_{(99-100)}, \mathrm{AND}_{(0-1)}$. Tato skupina tvoří $6 \% \mathrm{z}$ celkového počtu analyzovaných zrn.

Vzhledem ke zjištění výrazného zastoupení kulmského materiálu ve valounech studovaných spodnobadenských klastik byly výsledky studia granátu porovnávány s výsledky prací Čopjakové (2007), Otavy - Gilíkové (1999) a Otavy et al. (2000, 2002). Čopjaková (2007) ve své práci vyčlenila významnou skupinu grosulár-almandinových granátů s variabilním obsahem pyropů a spessartinů. Tato skupina $\mathrm{v}$ podstatě odpovídá nejpočetnější skupině granátů lobodických vzorků. Z tohoto porovnání vyplývá, že analyzované granáty jsou podobné granátům ze spodní části myslejovického souvrství drahanského kulmu. Nejbližší povrchový výskyt spodní části myslejovického souvrství je v současnosti vzdálen přibližně $13 \mathrm{~km}$ z. směrem od studované oblasti. Srovnání s dalšími souvrstvími kulmu jsou méně prokazatelná, ale lze konstatovat, že jistá podobnost charakteru chemismu granátů je s granáty z hornin protivanovského souvrství drahanského kulmu analyzovaných Otavou et al. (2000) a Hartleym - Otavou (2001) a s granáty $\mathrm{z}$ hornin hornobenešovského souvrství jesenického kulmu analyzovaných Hartleym - Otavou (2001), Otavou - Gilíkovou (1999), Otavou et al. (2002). Nejbližší povrchový výskyt protivanovského souvrství je v současnosti vzdálen přibližně $40 \mathrm{~km}$ sz. směrem od zájmové oblasti a výskyt hornobenešovského je $25 \mathrm{~km} \mathrm{~s}$. od studované oblasti.

Pro spodnobadenské sedimenty byla předpokládána provenience také $\mathrm{z}$ hornin karpatské orogenní fronty (Nehyba - Buriánek 2004). Z výsledků valounové analýzy a výskytu světlých vápenců lze také předpokládat zdrojový materiál z oblasti flyšového pásma Západních Karpat. Porovnáním s výsledky studia chemismu detritických granátů z krosněnského souvrství (Stráník et al. 2007) byla zjištěna podobnost $\mathrm{s}$ charakterem granátů ze sedimentů lobodické oblasti, ovšem pro potvrzení bude třeba dalších analýz.

\section{Analýza rutilů a interpretace}

Rutil je velmi stabilní minerál, jehož výrazný výskyt v sedimentech ukazuje často na opakovanou resedimentaci. Koncentrace Fe se pohybuje v rozmezí 1030 až 8210 ppm, $\mathrm{z}$ čehož lze usuzovat na původ rutilů $\mathrm{v}$ metamorfovaných horninách. Obsah Cr a Nb bylo možné porovnat u 10 analyzovaných rutilů. Výsledky porovnání ukazují, že pouze jeden rutil má kladné hodnoty logaritmu $\mathrm{Cr} / \mathrm{Nb}$ a je tedy nejspíše metamafického původu. Zbylých devět rutilů je metapelitického původu (Zack et al. 2004; Triebold et al. 2007).

Všechny analyzované vzorky rutilů jsou metamorfního původu, což ukazuje na původ rutilů spojený především s opakovanou resedimentací. Jako pravděpodobné zdrojové horniny se tedy jeví horniny drahanského a jesenického kulmu.

\section{Závěr}

Z výsledků faciální analýzy vyplynulo, že litofacie A byla interpretována jako pravděpodobný produkt depozice hrubozrnné delty. Litofacie B je analyzována jako sediment uložený relativně nízkoenergetickým prouděním nejspíše v mořském prostředí. Litofacie $\mathrm{C}$ byla interpretována jako sedimenty nejspíše distálnějších partií mělkého moře.

Petrografická analýza ukázala, že studovaná spodnobadenská klastika jsou polymiktní. Výsledky valounové analýzy ukazují na dominantní zastoupení sedimentárních hornin ve zdrojové oblasti a na recyklaci zdrojového materiálu. Interpretace petrografie a výsledků analýzy granátů ukázaly jako možný zdrojový materiál horniny kulmu Drahanské vrchoviny, kulmu Nízkého Jeseníku a také horniny flyšového pásma Západních Karpat. Jako nejpravděpodobnější se z porovnání chemismu granátů jeví horniny spodní části myslejovického souvrství. Tyto výsledky podpořila i analýza rutilů.

\section{Poděkování}

Studium bylo prováděno v rámci grantu GA ČR 205/09/0103. $Z$ a recenzi a připomínky $k$ textu děkujeme $M$. Hanáčkovi a J. Otavovi. 


\section{Literatura}

Brzobohatý, R. - Cicha, I. (1993): Karpatská předhlubeň. - In: Přichystal, A. - Obstová, V. - Suk, M. (ed.): Geologie Moravy a Slezska, Moravské Zemské Muzeum a Př́rodovědecká fakulta Masarykovy univerzity Brno, 123-128. Brno.

Brzobohatý, R. - Cicha, I. - Kováč, M. - Rögl, F. (2003): The Karpatian - a Lower Miocene Stage of the Central Paratethys. Masaryk University, Brno.

Buday, T. - Paulík, J. (1959): Závěrečná zpráva Lobodice. - MS Geofond. Praha.

Čopjaková, R. (2007): Odraz změn provenience v psefitické a psamitické frakci sedimentů myslejovického souvrství. - Disertační práce, MS Masarykova univerzita. Brno.

Dlabač, M. - Menčík, E. (1964): Geologická stavba autochtonního podkladu západní části vnějších Karpat na území ČSSR. Rozpravy Československé Akademie Věd, Řada matematických a př́rodních věd, 74, 1. Praha. 58 str.

Dudek, A. (1980): The crystalline basement block of the Outer Carpathians in Moravia: Bruno -Vistulicum. - Rozpravy Československé Akademie Věd, Řada matematických a př́rodních věd, 90, 8, 1-85. Praha.

Hartley, A. J. - Otava, J. (2001): Sediment provenance and dispersal in a deep marine foreland basin: the Lower Carboniferous Culm Basin, Czech Republic. - Journal of the Geological Society, London, 158, 137-150.

Cháb, J. - Stráník, Z. - Eliáš, M. (2007): Geologická mapa ČR 1 : 500 000. - ČGS. Praha.

Kukal, Z. (1983): Rychlost geologických procesů. - Academia. Praha. 280 str.

Kukal, Z. (1985): Návod k pojmenování a klasifikaci sedimentů. - ÚÚG. Praha. 80 str.

Kukal, Z. (1986): Základy sedimentologie. - Academia. Praha. 466 str.

Miall, A. D. (1996): The Geology of Fluvial Deposits. - Springer Verlag. Berlin. 582 pps.

Nehyba, S. - Buriánek, D. (2004): Chemismus detritických granátů a turmalínů-příspěvek k určení provenience jemnozrnných neogenních sedimentů karpatské předhlubně. Acta Musea Moraviae, Sci. geol., Brno: MZM Brno, LXXXIX, 1, 149-159.

Nichols, G. (1999): Sedimentology and stratigraphy. - Blackwell Science. Oxford. 355 pps.

Onderka, V. (1992): Zhodnocení ložiskové struktury Lobodice z hlediska skladování svítiplynu a zemního plynu. - MS, disertační práce, PřF UK, Praha.

Otava, J. - Gilíková, H. (1999): Correlation of Lithological Markers within the Moravian-Silesian Culm. - GeoLines, 8, 51, 53-55, Praha.

Otava, J. - Sulovský, P. - Čopjaková, R. (2000): Změny provenience drob drahanského kulmu: statistické posouzení. - Geologické výzkumy na Moravě a ve Slezsku v roce 1999, 7, 94-98.

Otava, J. - Čopjaková, R. - Sulovský, P. (2002): Drahanský kulm - odraz hlavních změn provenience v asociaci klastických granátů a těžkých minerálů. - Moravskoslezské paleozoikum 2002, abstrakty, 27-28, Brno.

Powers, M. C. (1953): A new roundness scale for sedimentary particles. - Journal of Sedimentary Research, 23, 117-119.

Stráník, Z. - Hrouda, F. - Otava, J. - Gilíková, H. - Švábenická, L. (2007): The Upper Oligocene-Lower Miocene Krosno lithofacies in the Carpathian Flysh Belt (Czech Republic): sedimentology, provenance and magnetic fabrics. - Geologica Carpathica 58, 4, 321-332.

Svatuška, M. - Brandejská, D. - Jonáš, J. - Mylonasová, E. (1989): Geologická analýza struktury. - MS, VÚGI Brno.

Triebold, S. - von Eynatten, H. - Luvizotto, G. L. - Zack, T. (2007): Deducing source rock lithology from detrial rutile geochemistry: An example from the Erzgebirge, Germany. - Chemical geology, 244, 421-436.

Zack, T. - von Eynatten, H. - Kronz, A. (2004): Rutile geochemistry and its potential use in quantitative provenance studies. Sedimentary Geology, 171, 37-58.

Zapletal, J. (2004): Příspěvek k paleogeografickému vývoji sedimentace spodního badenu na střední Moravě. - Scripta. Fac. Sci. Nat. Univ. Masaryk Brun. Geology, vol. 31-32, 87-98. Brno.

Zapletal, J. (2005): Poznámky ke geologickému vývoji severozápadní části Hornomoravského úvalu. - Geologické Výzkumy Moravy a Slezska v r. 2004, 12, 69-71. 